Received 10.03.2016 Reviewed 13.08.2016 Accepted 19.08.2016

A - study design

B - data collection

C - statistical analysis

D - data interpretation

E - manuscript preparation

F - literature search

\title{
Transboundary water management priorities in Central Asia countries - Tobol River case study in Kazakhstan
}

\author{
Gulnara YUNUSSOVA ${ }^{1)}$ ABCDEF , Józef MOSIEJ ${ }^{2) ~ D E}$
}

\author{
${ }^{1)}$ Kostanay State Baitursynov University, Agrarian Biological Faculty, Department of Ecology, Kostanay, Kazakhstan; \\ e-mail: gulnara_yun@mail.ru \\ 2) Warsaw University of Life Sciences - SGGW, Faculty of Civil and Environmental Engineering, Department \\ of Environmental Improvement, Nowoursynowska str. 166, 02-787 Warszawa, Poland; e-mail: jozef_mosiej@sggw.pl
}
For citation: Yunussova G., Mosiej J. 2016. Transboundary water management priorities in Central Asia countries - Tobol River case study in Kazakhstan. Journal of Water and Land Development. No. 31 p. 157-167. DOI: 10.1515/jwld-2016-0047.

\begin{abstract}
Changes in transboundary water resources management in Central Asia brought the river pollution issue even more up to date than runoff and water distribution problems. This survey demonstrates that the analysis of river flow dynamics. Their water consumption and pollution makes it possible to prioritize these aspects of water management.

As in the case of the Tobol-Torgay basin in Kazakhstan it was shown that for this type of basins. anthropogenic pollution remains a priority factor in transboundary water management. The Tobol River a tributary of the $\mathrm{Ob}$ and the Irtysh rivers belongs to the Kara Sea basin and is situated in the territory of Kazakhstan and Russia. Tobol-Torgay River basin located within borders of Kostanay region of Kazakhstan covers the upper reaches of the Tobol River and its tributaries. It has been determined that the water quality of the rivers in the region is stable for the decade under study and its formation remains due to natural factors. The priority contaminants in the basin are heavy metals and organic matter introduced by anthropogenic sources.

The idea of the article was to present the issues of cross-border water management, one of the largest in terms of area countries in the world (ranked 9th in the world in terms of area), Kazakhstan. In the scientific community involved in water management Kazakhstan is usually associated with a catchment area of two large bodies without the possibility of outflow - the Aral Sea and the Caspian Sea.
\end{abstract}

Key words: anthropogenic input, Ob and Irtysh rivers, pollution, Tobol-Torgay Water Basin

\section{INTRODUCTION}

Over the past two decades, transboundary water resources management problems have emerged and exacerbated in Central Asia. Geographical location and the transboundary nature of these rivers determine the specific nature of water use in each country in the region. "Upstream countries" (Tajikistan, Kyrgyzstan) mainly use the river water for hydroelectric energy generation. while "downstream countries" (Kazakhstan, Turkmenistan, Uzbekistan) use it mainly for irrigation of agricultural fields. All along the river flow water for industrial and domestic use is being abstracted [KURTOV 2014]. Approximately 90\% of the available water resources in Central Asia are being already used [GRINYAEV, FOMIN 2009]. The researchers KURTOV [2014], SIDOROVA [2008] and PORYADIN [2014] point out that in terms of water scarcity, population growth and economic development of the countries in recent decades, the problem of rational use of transboundary rivers has worsened and became a mechanism of mutual economic and political pressure in the region. Tensions between the region's countries have already cost $\$ 1.7$ bln or 3\% of GDP [PROON 2005]. 
As a result of dry climate Kazakhstan is a country suffering from water shortages. The river network of the country is underdeveloped. There are frequent river is not escaping into any body of water, but drying up in the sands of the deserts and rivers periodically. Maximum rivers flows are spring - the time of melting snows on the steppes.

Water resources of the Republic of Kazakhstan (the RK) are concentrated mainly in the basins of the Amu Darya and Syr Darya Rivers which belong to the Aral Sea basin, and are also part of the Caspian Sea and the Kara Sea. The total surface water resources of Kazakhstan for the period 1974-2008 [PORYADIN $2014]$ totaled $91.3 \mathrm{~km}^{3} \cdot \mathrm{year}^{-1}(50 \%$ coverage of needs), of which $44.3 \mathrm{~km}^{3}$ come from neighboring countries, and $47.0 \mathrm{~km}^{3}$ is comprised by the local flow. Economic sectors in this period had been using about $60-70 \%$ of the surface water resources (Fig. 1).

However, the available water supply varies greatly at the regional level. So, the level of water supply for the industries in Karaganda, Akmola, North Kazakhstan, Kostanay and Aktobe regions was in the 53-90\% range [SIDOROVA 2008].

According to the State Hydrometeorological Observation Service for the 1941-2012 period, the average annual precipitation in Kazakhstan have decreased slightly - by $0.6 \mathrm{~mm}$ per 10 years or about $0.4 \%$ of the norm per 10 years [Agentstvo po statistike RK 2013]. On average, in Kazakhstan a slight tendency (statistically insignificant) towards a decrease in rainfall of about $0.7 \mathrm{~mm}$ per 10 years is observed in all seasons, except for the winter season, when the trend of increase in rainfall comprises 1.4 $\mathrm{mm}$ per 10 years $(1.8 \%$ of the norm per 10 years $)$.

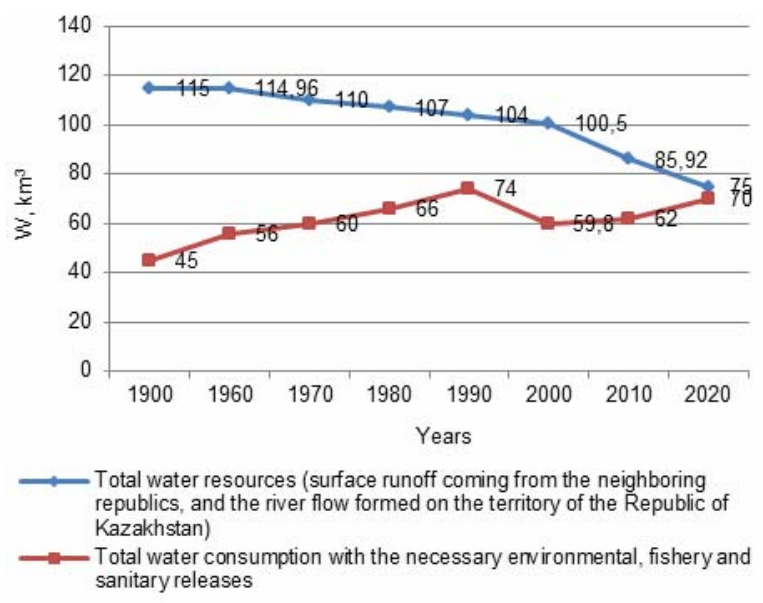

Fig. 1. Water resources and water consumption $\left(\mathrm{km}^{3}\right)$ in the Republic of Kazakhstan; source: Pravitel'stvo RK [2010]

Structural changes in the economy of the recent years have also changed the water consumption structure. In the $90 \mathrm{~s}$ the main consumers and polluters of water resources in Kazakhstan were agricultural $(78 \%)$, industrial $(16 \%)$ domestic (less than 5\%) sectors and other consumers (1\%) [GRID-Arendal 1998].
In $2003-2013,51 \%$ of surface water was used in the agricultural sector, $41 \%$ in the industrial sector, $4 \%$ in households, $9 \%$ in other types of economic activities, $2 \%$ in forestry and fisheries [DZHUATOVA, SEYDULLAEVA 2014]. The largest share of agricultural water use accounts for irrigation agriculture crops, then for surface (liman) irrigation for fodder production during spring period, irrigation of grasslands during the vegetation period and water supply for the rural population and livestock [SIDOROVA 2008]. According to the data obtained, due to the growth of economic activity and climate change, river flow resources in Kazakhstan decreased by $21 \%$, of that $26 \%$ due to the transboundary runoff, $14 \%$ due to the local runoff [PORYADIN 2014].

Currently water consumption in Kazakhstan tends to increase by $1 \%$ per year on average [PROON 2004]. This will result in $90 \%$ use of surface water in 2020 , which greatly exceeds the norm of ecological river runoff [Institut geografii... 2010]. Therefore, the volume of water consumption in Kazakhstan has to be limited to the level of water consumption in 2010 [Pravitel'stvo RK 2010].

An important part of this agreed transboundary water management issue is the problem of internal (within the state) water pollution and transboundary pollutants transfer. The contamination level and the quality of river water are controlled through the monitoring both by state (internal) monitoring network and at transboundary checkpoints. Of the 69 monitored rivers in Kazakhstan in 2011 only 9 rivers were under "pure" quality category [Kazgidromet 2012]. In recent years, intensive studies are carried out to quantify the transboundary pollution of rivers in Kazakhstan, mainly the Aral Sea basin [BURLIBAEV et al. 2012; 2013; SEVERSKIY 2004].

Similar studies on the Tobol-Torgay basin are not known. Therefore assessment of anthropogenic load on the river basin and the role of transboundary transfer in terms of transboundary monitoring priorities is of current interest.

Kostanay region is located within the Tobol-Torgay Water Basin (TTWB) (Fig. 2), the poorest basin in terms of water resources in Kazakhstan. Approximately $70 \%$ of the average long-term runoff of the basin is concentrated in Kostanay region [RGP... 2011]. Its total area comprises $214000 \mathrm{~km}^{2}$, water resources volume is $2.9 \mathrm{~km}^{3}$, of which $35 \%$ are concentrated in the rivers. About 1 million people live within the basin. Industrial water supply from the waters of the Tobol-Torgay River basins is $89 \%$ (50\% of the water supply) [GRID-Arendal 1998].

Several rivers in Kostanay region are transboundary: Tobol, Ayat, Uy, Ubagan, Togyzak. Of these, the Tobol River is the main river of the basin and the rest are its tributaries (Fig. 3b). The Tobol is a typical lowland river, $90 \%$ of the annual flow is generated during snow cover melting [DEJNEKA 2010]. Of the $1591 \mathrm{~km}$ total river length, $682 \mathrm{~km}$ lie in Kostanay region. 


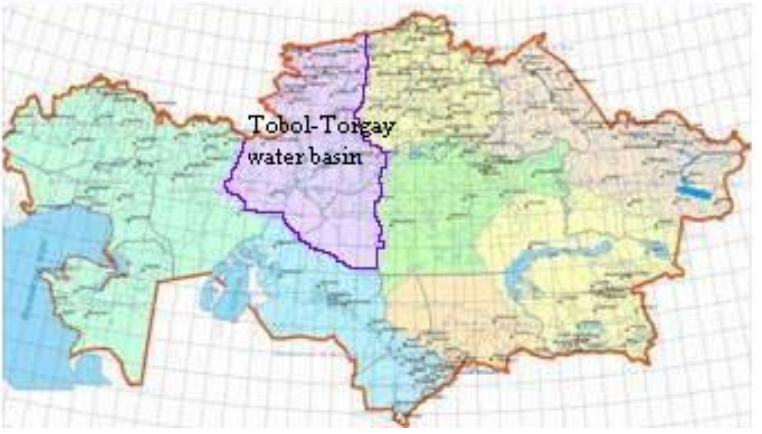

Fig. 2. Water basins in Kazakhstan; source: PROON [2004]

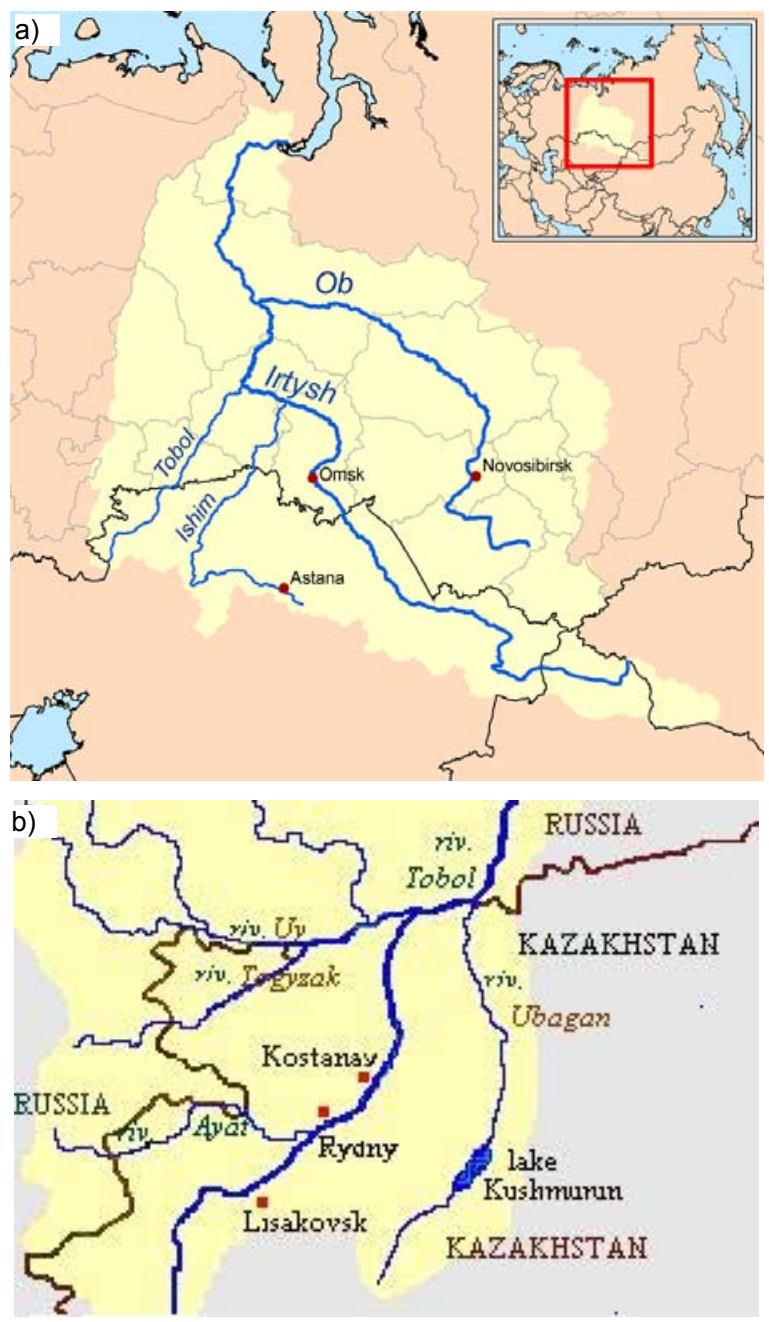

Fig. 3. Ob with Irtysh (a) and Tobol River (b) basins; source: wikipedia [undated] and own elaboration

It is the left and the most high-water inflow of the Irtysh River a tributary of the Ob River of the Kara Sea basin (Fig 3a). Within the Irtysh River basin up to half of renewable resources of the republic is generated [MEDEU et al. 2012] and the greatest amount of wastewater is discharged [GAZALIYEV (ed.) 2014].

The total water resources of the TTWB in average year amount to $2.12 \mathrm{~km}^{3} \cdot \mathrm{year}^{-1}$, including that of the Tobol basin $-0.75 \mathrm{~km}^{3} \cdot$ year $^{-1}$, the Torgay basin $1.37 \mathrm{~km}^{3} \cdot$ year $^{-1}$. In dry years they amount to 0.19 $\mathrm{km}^{3} \cdot \mathrm{year}^{-1}$, including that of the Tobol basin -0.09 $\mathrm{km}^{3} \cdot \mathrm{year}^{-1}$ and the Torgay basin $-0.1 \mathrm{~km}^{3} \cdot \mathrm{year}^{-1}$ [PK... 2006]. Withdrawn water is used for different economic needs like industry, agriculture and public water supply. In the basin of the Torgay River, due to the very uneven flow distribution within the year and from year to year, and due to the lack water storage reservoirs, the water resources of the rivers are almost not used for water supply and regular irrigation.

\section{METHODS AND MATERIALS}

Integrated assessment of anthropogenic load on the TTWB (Tobol-Torgay Water Basin) rivers was based on the DPSIR cause-effect relations model [KRISTENSEN 2004]:

- analysis of the dynamics of water consumption indicators,

- TTWB rivers' pollution analysis,

- analysis of the transboundary components transfer,

- combined analysis of the data received in terms of transboundary monitoring priorities.

Analysis of the water consumption indicators dynamics was carried out on the following indicators:

- the annual flow of the Tobol River,

- surface water intake,

- surface water used,

- amount discharged into water bodies,

- the structure of water consuming industries,

- primary water users number,

- urban and rural population number in Kostanay region.

The data was collected from the annual statistical books of the Agency of the Republic of Kazakhstan on Statistics (ARKS), Kostanay Department of Ecology, Kostanay Hydrometeorological Centre, TTWB in Kostanay region in 2000-2012.

Analysis of pollution of the TTWB rivers was conducted based on the results of calculation of integral water quality indicators WPI (water pollution index) and IWPIwa (integral water pollution index weighted average), and also in terms of BOD and dissolved oxygen. The calculation of integral water quality indicators of WPI and IWPIwa made in accordance with standardized methods [Goskomgidromet SSSR 1986; MOOS 2012], when the measured concentration of the detected contaminants is compared to the corresponding maximum permissible concentration (MAC) [PDK, OBUV 1990; Sanitarno-epidemiologicheskie... 2004], and then integral indicators are calculated. In both methods the calculation involves the entire list of supervised pollutants. The methods differ in the way of aggregation for integral index values. WPI calculation is performed on six priority pollutants and allows evaluation of the overall pollution in the studied point. IWPIwa calculation is the reflective of the contribution of individual chemical contaminants groups in the total pollution: major ions $\left(\mathrm{Ca}, \mathrm{Mg}, \sum(\mathrm{Na}+\mathrm{K})\right.$, $\mathrm{SO}_{4}, \mathrm{Cl}$, etc.); biogenic elements $\left(\mathrm{NH}_{4}, \mathrm{NO}_{3}, \mathrm{NO}_{2}\right.$, $\mathrm{P}_{\text {tot, }}$, phosphates, Si etc.), heavy metals (iron, and other metals); toxic substances (CN, SCN, F, H $\mathrm{H}_{2}, \mathrm{~S}, \mathrm{As}$, 
nitrobenzene etc.); organic substances (oil, resin, carbohydrates, fats, phenols, synthetic surfactants, furfural etc.); organochlorine pesticides. During the calculation of WPI and IWPIwa the data from the state monitoring network on the concentrations of the 27 components in the water of the Tobol River and its tributaries Ayat, Ubagan, Togyzak over 2000-2011. During the WPI calculation the fact that such components as iron, nickel and manganese have universally high background values, due to their significantly higher concentrations in the rocks of the Tobol catchment area and in groundwater feeding the river [DEJNEKA 2010].

Assessment of water pollution in terms of BOD and dissolved oxygen is made according to a standardized methodology according to the state monitoring network data over 2000-2011 [MOOS 2012].

Transboundary contaminants transfer assessment along the rivers of Tobol-Torgay basin was made in compliance with standardized methodology according to the state monitoring network data on the pollutants content and the average monthly water consumption in 2011 [Kazgidromet 2011; Pravitel'stvo RK 2012].

\section{RESULTS AND DISCUSSION}

Water use and disposal indicators change dynamics over 2000-2012 is depicted in Figures 4-9. The analysis of these data allowed defining the changes in water use factors in the basin over the period.

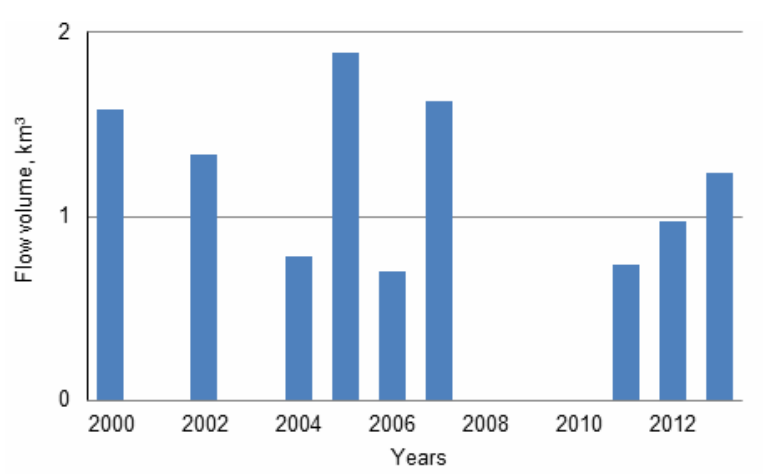

Fig. 4. The annual flow volume $\left(\mathrm{km}^{3}\right)$ of the Tobol River; source: own elaboration

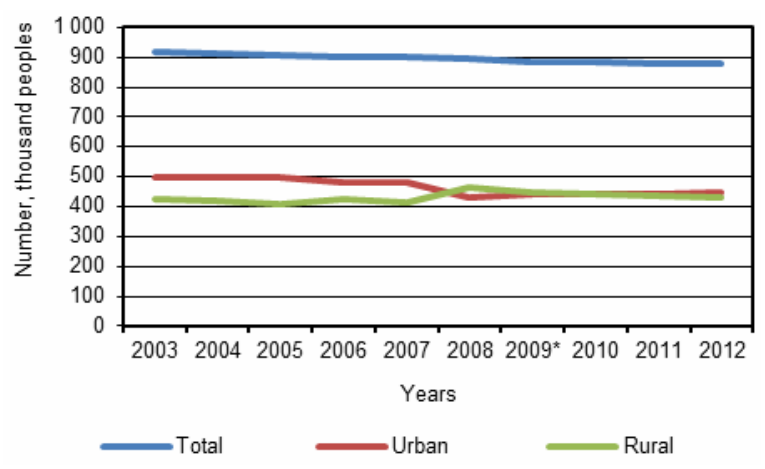

Fig. 5. Dynamics of the population of Kostanay region; source: own elaboration

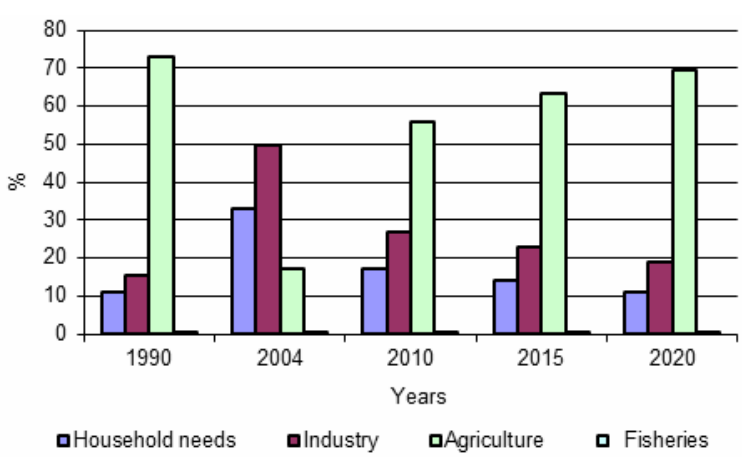

Fig. 6. Current and future structure of water consuming sectors in the Kostanay region, \% of total water consumption; source: own elaboration

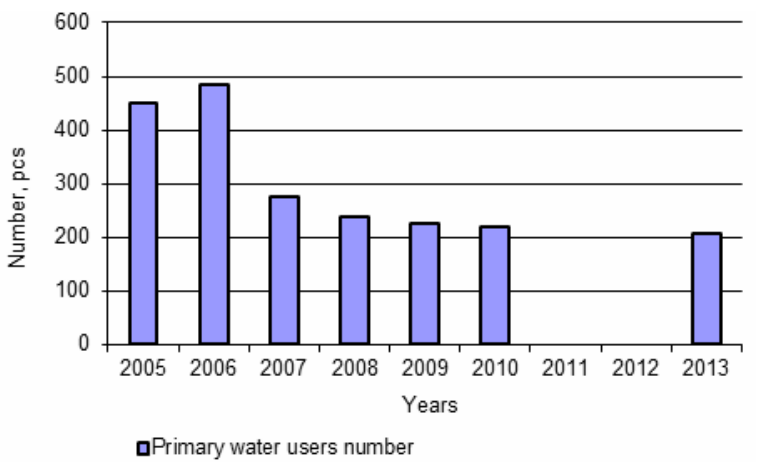

Fig. 7. Primary water users number dynamics in the Kostanay region, the number of items; source: own elaboration

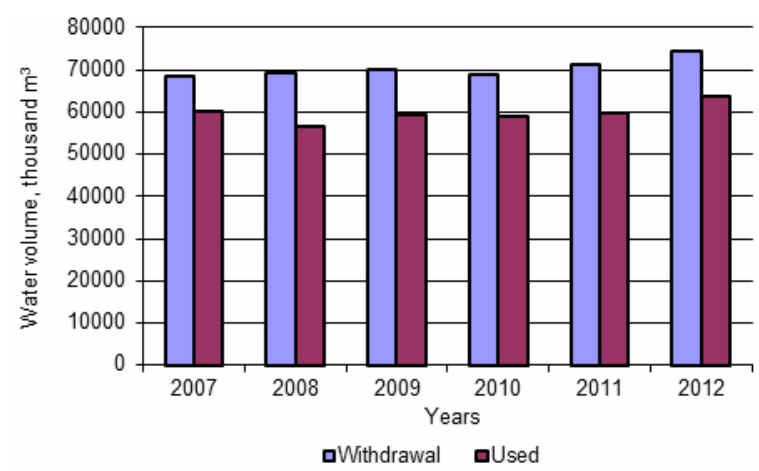

Fig. 8. Dynamics of "surface water withdrawal - surface water used" indicators in Kostanay region, thousands $\mathrm{m}^{3}$; source: own elaboration

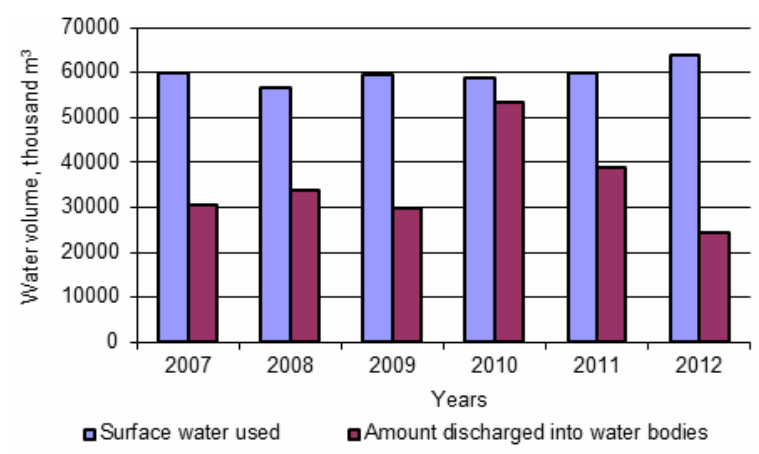

Fig. 9. Dynamics of "surface water used - amount discharged into water bodies" indicators in Kostanay region, thousands $\mathrm{m}^{3}$; source: own elaboration 
Figure 4 illustrates the variability of the Tobol River flow. The annual flow significantly fluctuates in wet and dry year's cycles.

A comparison of the Figures 5-7 allows making conclusions about changes in the water consumers' structure. The total population of the region decreased by $4 \%$ in the period under review, and urban $-10 \%$, but the rural - has increased by $2 \%$. It is likely to have affected the results of the migration policy of resettlement of returnees. Number of enterprises, the primary water users (industrial and agricultural) increased. In this case, obviously, in the years 20002011 basic primary water users were small enterprises, since 2011 - the large enterprises.

In the period 2001-2010 in Kostanay region the volume of industrial production increased by 7.2 times and the volume of gross output of agriculture in the region increased 2.6 times. Thus, the impact of large industrial enterprises as the water users, compared with the population and agricultural enterprises has increased [Upravlenie... 2011].

A comparison of the Figures 5-7 allows to draw conclusions about the structure of water use change. Thus, over period 2007-2012 the ratio of "use of surface water/intake of surface water" indicators ranges from $82 \%$ (2008) to $87.7 \%$ (2007); the average for the period is $85 \%$. Ratio of "amount discharged into water bodies/use of surface water" ranges from 38\% (2012) to $90 \%$ (2010); the average for Kostanay region is $60 \%$. Then, about $50 \%$ of withdrawn surface water does not return into the water bodies. With the relative stability of the volume of abstracted water and the volume of the used water, significant irregularity of the discharged volume of water is witnessed. Water losses during its use comprises approximately $15-25 \%$

Comparison of water consumption indicators (Fig. 8) in the Kostanay region to the Tobol River runoff (Fig. 4) indicates that the amount of water use in dry years is comparable to the runoff, but in wet years - is half of it. The constancy of the volume of water abstracted and used taking into account the reduction of atmospheric precipitation indicates a trend of slow decrease in runoff of Kostanay region rivers [Agentstvo po statistike RK 2013].

Until 1975, from located on the banks of the rivers cities (Kostanay, Rudny, Zhitikara) delivered insufficiently treated domestic sewage and industrial effluents in the Tobol River. Registered were 10 issues of sewage, 6 of which were in Kostanay. Currently in Kostanay region produced only 2 authorized discharge into the river. Other enterprises use purified water in the water cycle, recycled or dumped into the man-made ponds [ZHAKAEV 2007].

The results of river water pollution assessment by the water pollution index WPI in the observation points of transboundary rivers in Kostanay region are shown in Figure 10. The Tobol River, Syntasty River and Uy River flow into Kostanay region from Russian territory. The Tobol River, Togyzak River and Uba- gan River flow out from Kostanay Region to Russian territory. "Input" observation points is the Ayat River in hydrological cross section Varvarinka village. "Output" observation points are the cross sections of the Ubagan River in Aksuat village, for the Togyzak River in Togyzak station and for the Tobol River in Milutynka village.

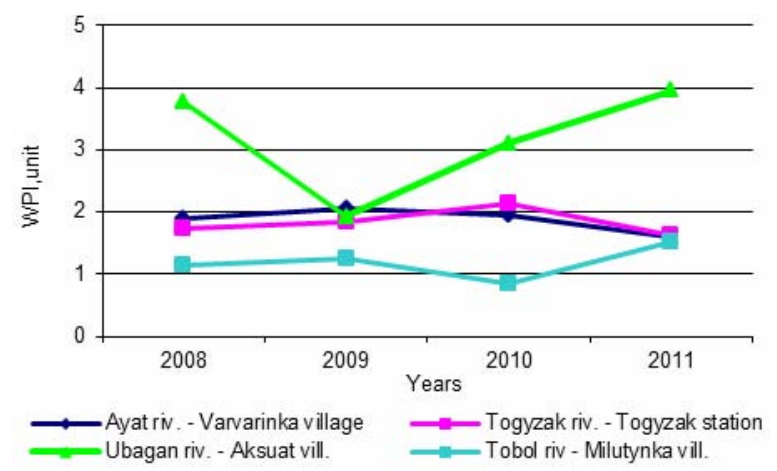

Fig. 10. Water quality in the inlet and outlet observation points of the basin's rivers in terms of water pollution index (WPI); source: own elaboration

The diagram shows that the water quality in the input alignment is worse than in the outlet. These data are confirmed by the ARKS data on the rivers for the broader period of 2000-2010 (Tab. 1) [Agentstvo po statistike RK 2013].

Table 1. The water quality of the Tobol River in terms of water pollution index $W P I$

\begin{tabular}{|c|c|c|c|c|c|}
\hline Year & $W P I$ & $\begin{array}{c}\text { Degree of } \\
\text { water quality }\end{array}$ & Year & $W P I$ & $\begin{array}{c}\text { Degree of } \\
\text { water quality }\end{array}$ \\
\hline 2000 & 0.51 & 2 & 2005 & 0.46 & 2 \\
\hline 2001 & 0.55 & 2 & 2006 & 0.46 & 2 \\
\hline 2002 & 0.53 & 2 & 2007 & 1.76 & 2 \\
\hline 2003 & 0.60 & 2 & 2008 & 1.33 & 3 \\
\hline 2004 & 0.66 & 2 & 2009 & 1.56 & 3 \\
\hline
\end{tabular}

Source: own study.

In general, despite the fact that some of the tributaries (the Togyzak River, and sometimes the Ubagan River) bring more contaminated water, the water quality of the Tobol River, the main river of the basin, along the entire river length is characterized as "moderately polluted" ( $3{ }^{\text {rd }}$ quality class) in terms of WPI. Thus, the gradual dilution of pollution is observed downstream the Tobol River. Simulation of contaminant transfer by water streams through the example of copper confirmed that the concentration for introduced anthropogenic pollution with heavy metal falls a short distance from the source [PAVLICHENKO et al. 2009].

River water pollution assessment by use of the integral water pollution index weighted average $I W$ PIwa, on the basis of monitoring data has shown the presence of the following groups of elements of contaminating components. The group of major ions chlorides, sulfates, sodium, magnesium, calcium; biogenic elements group - ammonium nitrogen, nitrite 
nitrogen, nitrate nitrogen, phosphates, silicon; in the group of heavy metals - copper, zinc, nickel, cobalt, manganese, chromium $\left(\mathrm{Cr}^{6+}\right)$, total iron; in the group of toxic substances - fluorides; in the group organic substances - volatile phenols, petroleum products, resins, synthetic surfactants; in the group of organochlorine pesticides - no measurements.

The results of calculation of IWPI in the groups of components and integral IWPIwa are shown in the Figures 11-12.
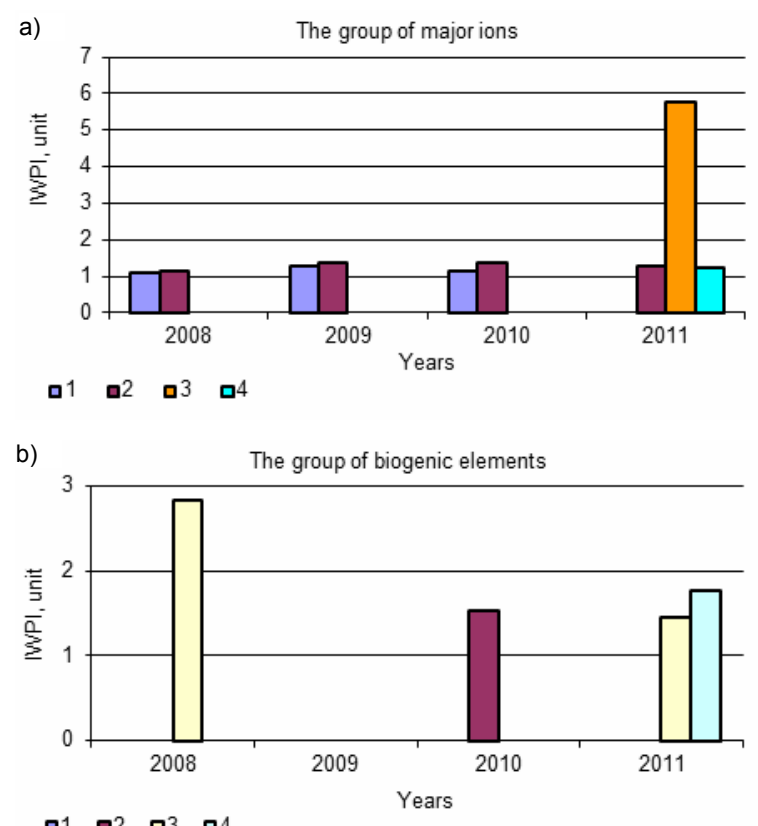

$\begin{array}{llll}\square 1 & \square 2 & \square 3 & \square 4\end{array}$

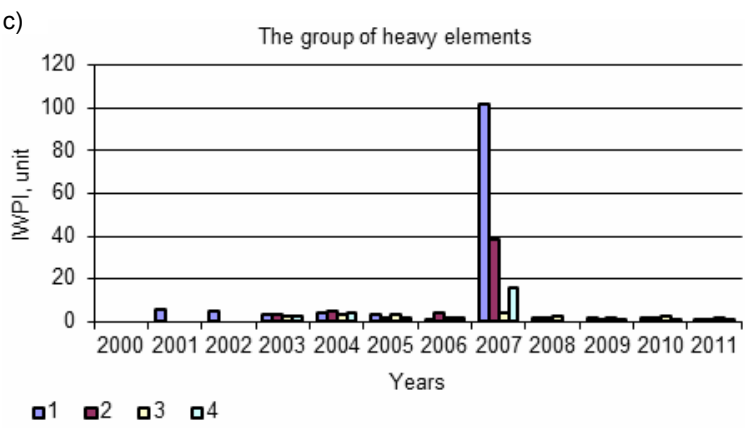

$\begin{array}{llll}\square 1 & \square 2 & \square 3 & \square\end{array}$

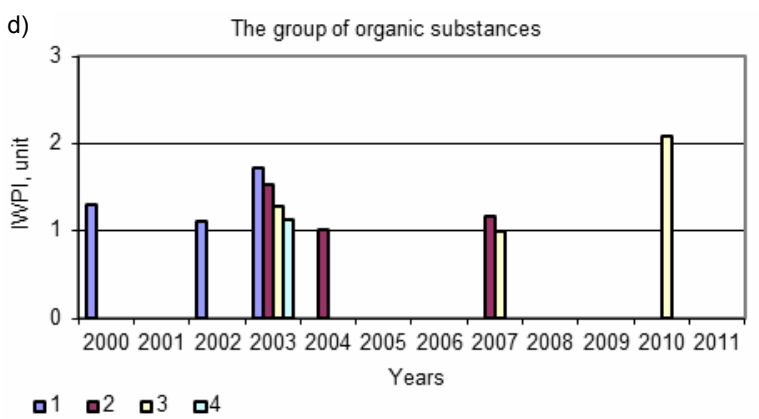

Fig. 11. Integral water pollution index IWPI dynamics in the groups of ions at the observation points: $1=$ the Ayat River

- Varvarinka village; 2 = the Togyzak River - Togyzak station; 3 = the Ubagan River - Aksuat village; $4=$ the Tobol River - Milutynka village; source: own study

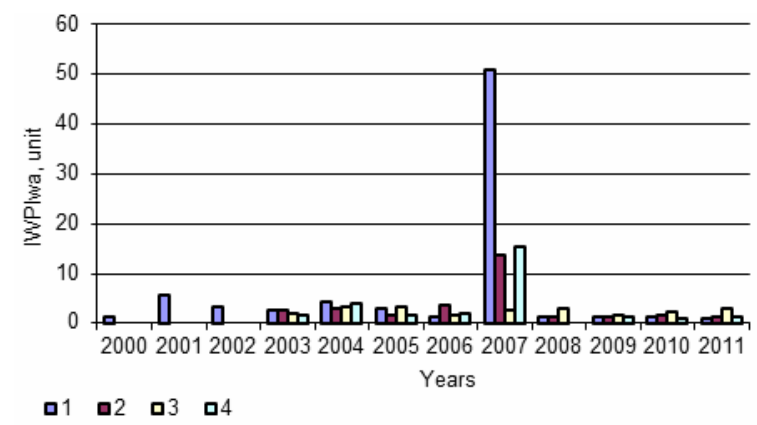

Fig. 12. Integral water pollution index weighted average IWPIwa dynamics on observation points: $1-4$ as in Fig. 11; source: own study

Thus, over 2000-2011 in all the hydrological cross sections, the highest MAC excess over the period of measurements was recorded for groups of heavy metals and major ions. Overall surface water pollution is due mainly to heavy metals, except data in 2007, MAC was constantly exceeded 1-5 times. The contribution of other contaminants groups decreases in the row: biogenic elements, organic substances. Excess of the MAC for the group of major ions observed occasionally. Toxic substances (fluorides) in the concentration exceeding the MAC were only found sporadically.

According to experts [DEJNEKA 1996; 2010] in the water of TTWB rivers, naturally there is a significant amount of biogenic compounds (nitrogen, phosphorus compounds) and heavy metals [DEJNEKA 1996; 2010]. Set of elements in river water is largely predetermined by the geological and morphological conditions and landscape conditions of the watershed: deposits of iron, aluminum, copper-gold, nickelcobalt ores in the upper reaches of the Tobol River, mineralized groundwater inflow, steppe soil, salt marshes, agricultural landscapes. The natural hydrochemical background of Trans-Urals natural waters where the Tobol basin is located includes copper, zinc, iron, manganese, fluorides. Additional quantities of heavy metals are associated with the mining activity of the enterprises in Kostanay region. In 1995, excess in terms of heavy metals (average value) was witnessed: total iron -3.9 times, copper -11.5 times and manganese -16 times.

In the absence of domestic sources of pollution nitrate pollution was detected in concentration of 4-7 $\mathrm{mg} \cdot \mathrm{dm}^{-3}$ [URYVAEV (ed.) 1959]. The Tobol River water in 1995 contained an increased amount of nitrates $\left(90 \mathrm{mg} \cdot \mathrm{dm}^{-3}\right.$ in summer), organic substances $\left(50 \mathrm{mg} \cdot \mathrm{dm}^{-3}\right)$ [DEJNEKA 1996].

Natural geochemical status of groundwater feeding the rivers in the region and having impact on their chemical composition was determined through the analysis of the literature references. The study area is located in the territory of natural hydro geochemical provinces in groundwater and underlying aquifer [MIRONENKO et al. 1988; VESELOV et al. 1993]. The mechanisms of their formation are disclosed. In the arid zones sulfates and chlorides of calcium, magne- 
sium and sodium are accumulated in the groundwater through evaporative concentration over rainwater feed area. Conditions for the accumulation of boron and arsenic in groundwater of the natural area emerge. In the underlying aquifers with low oxidation-reduction potential values. divalent iron, divalent manganese, ammonium ion abnormalities are formed. In waters of sulfide deposits with increasing oxidation-reduction potential $\mathrm{Zn}, \mathrm{Pb}, \mathrm{Se}, \mathrm{Cd}$ are accumulated [KALINNIKOV et al. 2002].

The results of water pollution assessment in terms of BOD and dissolved oxygen are shown in Figures 13-14.

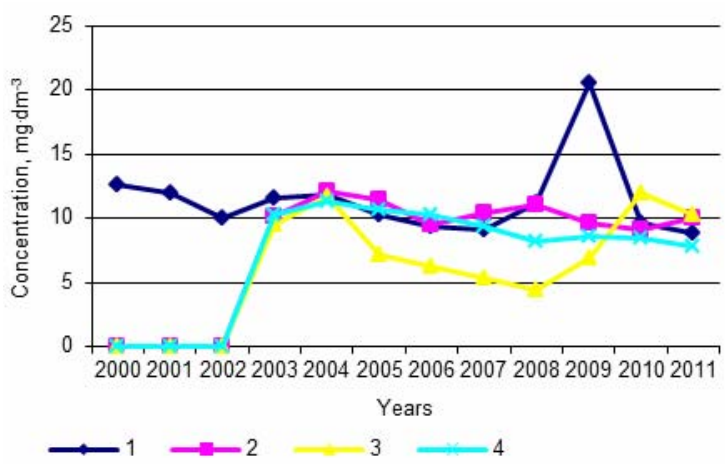

Fig. 13. Dissolved oxygen content $\left(\mathrm{mg} \cdot \mathrm{dm}^{-3}\right)$ change dynamics in the observation points: $1-4$ as in Fig. 11; source: own study

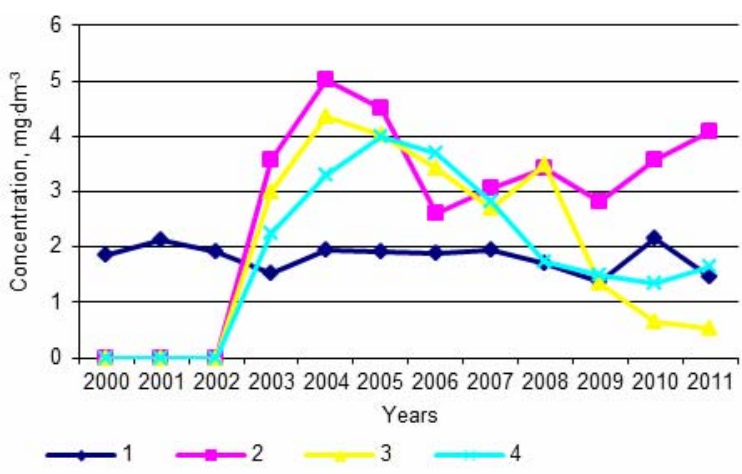

Fig. 14. BOD $\left(\mathrm{mg} \cdot \mathrm{dm}^{-3}\right)$ change dynamics in the observation points: 1-4 as in Fig. 11; source: own study

Joint analysis of the water quality assessment data in terms of IWPIwa for the groups of organic substances and biogenic elements (Fig. 11b, d) and BOD and dissolved oxygen dynamics (Fig. 13-14) shows that over the decade studied the input of these contaminants by the Ubagan and Togyzak tributaries; that leads to increased levels of pollution in the downstream of the Tobol River. Excess of MAC for detected organic and biogenic contamination was observed infrequently, and rarely for the group of biogenic pollution. However, natural self-purification capabilities of the Tobol waters are not exhausted, as the concentration of organic and biogenic contaminants exceeds MAC standard irregularly, and the water quality varies within a reasonable range. Visibly overgrown shores of the Tobol indicate that these concentrations are enough for fast eutrophication in some sections of the rivers.

The calculation of transboundary contaminants transfer mass by the Tobol River and its tributaries on the hydrochemical cross sections allows us to understand how much and what contaminants flow into the territory of a neighboring state, and what is the balance of substances transfer within the Kostanay region. The calculations performed for the year 2011 . The results of calculation of transboundary contaminants transfer mass by the Tobol River and its tributaries on the section is shown in Table 2. The calculation on the Ubagan River - Aksuat village hydrological cross sections was not made, as there was no runoff in the that year.

Calculations show that during high water and flooding periods more components such as organic substances, chlorides, the sum of ions ( $\mathrm{Na}, \mathrm{Ca}, \mathrm{Mg}$ ) ammonium nitrogen, silicon, copper, nickel, manganese, fluoride, were added by the Ayat River than removed away through the Togyzak and the Tobol rivers. During low-water periods, removal prevails for all components in the water. Within the year such components as silicon, copper and manganese had a positive balance, their addition predominated over the removal. For all other considered pollutants removal prevailed over addition. Maximum weight of the transboundary transfer was observed for sulfates, chlorides, the sum of ions, manganese, and the minimum - for nitrite nitrogen, total phosphorus and fluorides.

From data in Table 2 it is known that via the Tobol River there was transboundary removal of organic contaminants (0.68 thous. $\mathrm{t}$ ), major ions (the total amount 106.13 thous. t), biogenic components (total 2.41 thous. t), heavy metals (total for iron, zinc and nickel together -2.12 thous. $t$ ) from the territory of Kostanay region in 2011.

The total mass removal comprised 113.08 thous. $t$. Total load of addition (silicon, copper, manganese, fluorides) amounted to 45.53 thous. t. Thus in Kostanay region river load of water pollution is increasing by 67.55 thous. $t$ ( $59.7 \%$ of removal load).

Water pollution of the Ayat River draws attention. For some components (silicon, copper, manganese, fluorides), calculated weight of additions in the Varvarinka - the Ayat River section was higher than the removal weight in output section Togyzak station - the Togyzak River and Milutynka village - the Tobol River output hydrochemical cross section.

In the territory of Kurgan and Tyumen regions of Russia the Tobol River pollution increases due to the impact of dozens of industrial discharges. Therefore, it is important that the pollution of TTWB rivers did not increase a moderate level, and complied to $3^{\text {rd }}$ class of water quality. This will satisfy both domestic (Kazakhstan) and external (Russian) requirements for water quality of the Tobol River. 
Table 2. Transboundary contaminants transfer on the observation point of the Tobol River and its tributaries in 2011

\begin{tabular}{|c|c|c|c|c|c|c|c|c|c|c|c|c|c|c|c|c|c|}
\hline \multirow[b]{2}{*}{ 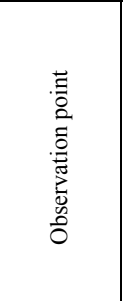 } & \multirow[b]{2}{*}{ 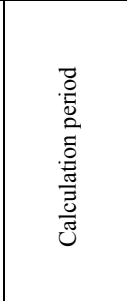 } & \multirow[b]{2}{*}{ 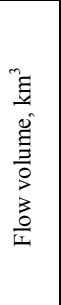 } & \multicolumn{15}{|c|}{ Components } \\
\hline & & & 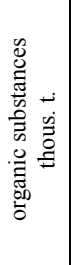 & 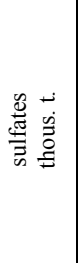 & 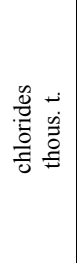 & 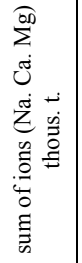 & 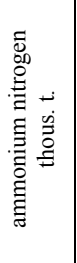 & 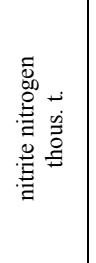 & 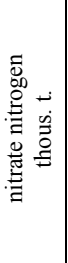 & 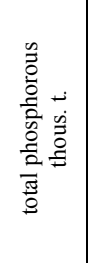 & 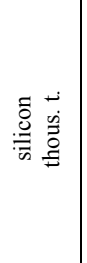 & 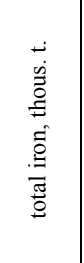 & 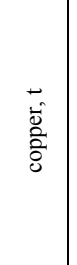 & $\stackrel{\overrightarrow{0}}{\stackrel{\Xi}{N}}$ & 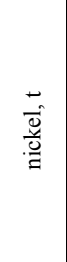 & 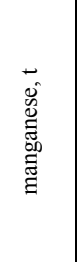 & 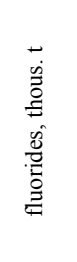 \\
\hline \multirow{3}{*}{$\begin{array}{l}\text { The Ayat } \\
\text { River - } \\
\text { Vavarinka } \\
\text { village }\end{array}$} & high water ${ }^{1)}$ & 0.65 & 2.69 & 71.61 & 83.31 & 124.02 & 0.42 & 0.01 & 0.23 & 0.04 & 2.80 & 0.10 & \begin{tabular}{l|l}
3.03 \\
\end{tabular} & 0 & 4.12 & 244.83 & 0.24 \\
\hline & low water & 0.03 & \begin{tabular}{l|l}
0.09 \\
\end{tabular} & 4.38 & 5.57 & 8.25 & 0.01 & \begin{tabular}{l|l|}
0.0002 \\
\end{tabular} & 0.01 & 0.0004 & 0.04 & 0.01 & $\begin{array}{ll}0.07 \\
\end{array}$ & 0.01 & 0.24 & 4.68 & 0.01 \\
\hline & over the year & 0.68 & 2.78 & 75.99 & 88.88 & 132.27 & 0.43 & 0.01 & 0.24 & 0.04 & 2.84 & 0.11 & 3.10 & 0.01 & 4.36 & 249.51 & 0.25 \\
\hline \multirow{3}{*}{$\begin{array}{l}\text { The Togyzak } \\
\text { River - } \\
\text { Togyzak } \\
\text { station } \\
\end{array}$} & high water & 0.10 & 1.11 & 24.79 & 9.15 & 29.68 & 0.05 & 0.003 & 0.11 & 0.02 & 0.38 & 0.05 & \begin{tabular}{l|l}
0.17 \\
\end{tabular} & 0 & 0.30 & 21.00 & 0.04 \\
\hline & \begin{tabular}{|l|} 
low water \\
\end{tabular} & 0.02 & 0.21 & 4.91 & 3.99 & 6.36 & 0.01 & 0.0003 & 0.01 & 0 & 0.03 & 0.005 & 0.04 & 0.02 & 0.58 & 4.73 & 0.003 \\
\hline & over the year & 0.12 & 1.32 & 29.70 & 13.15 & 36.05 & 0.05 & 0 & 0.13 & 0.02 & 0.41 & 0.05 & 0.20 & 0.02 & 0.88 & 25.73 & 0.04 \\
\hline \multirow{3}{*}{$\begin{array}{l}\text { The Tobol } \\
\text { River - } \\
\text { Milutynka } \\
\text { village }\end{array}$} & high water & 0.30 & 1.45 & 54.18 & 48.63 & 68.63 & 0.31 & 0.05 & 2.18 & 0.08 & 1.68 & 0.20 & 0.90 & 0 & 1.00 & 142.30 & 0.12 \\
\hline & \begin{tabular}{|l|} 
low water \\
\end{tabular} & 0.18 & 0.69 & 46.16 & 44.04 & 62.73 & 0.08 & \begin{tabular}{l|l}
0.01 \\
\end{tabular} & 0.21 & 0.01 & 0.32 & 0.04 & 0.46 & 0.12 & 4.28 & 39.99 & 0.03 \\
\hline & over the year & 0.48 & 2.14 & 100.34 & 92.67 & 131.36 & 0.39 & 0.06 & 2.39 & 0.09 & 2.00 & 0.25 & 1.36 & 0.12 & 5.28 & 182.29 & 0.14 \\
\hline \multirow{3}{*}{ Total } & high water & & 0.13 & -7.36 & 25.53 & 25.71 & 0.06 & \begin{tabular}{l|}
-0.043 \\
\end{tabular} & -2.06 & -0.06 & 0.74 & -0.15 & 1.96 & 0 & 2.82 & 81.53 & 0.08 \\
\hline & low water & & -0.81 & -46.69 & -42.46 & -60.84 & -0.08 & -0.0101 & -0.21 & -0.0096 & -0.31 & -0.035 & -0.43 & -0.13 & -4.62 & -40.04 & -0.023 \\
\hline & over the year & & -0.68 & -54.05 & -16.94 & -35.14 & -0.01 & -0.05 & -2.28 & -0.07 & 0.43 & -0.19 & \begin{tabular}{l|l|}
1.54 & \\
\end{tabular} & -0.13 & -1.80 & 41.49 & 0.07 \\
\hline
\end{tabular}

1) During snow melting period.

Source: own study.

\section{CONCLUSIONS}

1. The level of contamination of the Tobol-Torgay Water Basin (TTWB) rivers remains moderate in the last decade. Pollution of rivers is mainly due to heavy metals and organic substances with a significant anthropogenic contribution.

On the local level, pollution of surface water can be determined by anthropogenic sources. However, geographically, that is within the region, environmental factors continue to play a leading role in the formation of the chemical composition of surface waters.

2. Such factors of the existing practice TTWB surface waters use practice as the constant volume of water consumption, distributed wastewater discharges, development of water recycling at large water consuming enterprises, sustain the condition where the capacity of the water environment in some important contaminants (heavy metals) is not exceeded. However, the water environment capacity for organic, biogenic pollution decreases gradually and eutrophication progress stays uncontrolled.

3 . The volume of water consumption in the region, apparently, is getting close to the limit value. Then hazardous would be a sharp increase in water intake which can lead to sharp fluctuations in flow and the impact of a sharp rise in the concentration of pollutants, accelerated eutrophication.

4. With regard to the further water pollution of the Tobol River in Russia, transboundary monitoring in Kazakhstan territory should aim to control the existing quality of the basin's rivers.

5. Analysis of flow dynamics, water consumption and pollution of TTWB rivers showed that anthropogenic pollution was more important for water management in the region as it has a greater impact on water quality than the runoff.

\section{REFERENCES}

Agentstvo po statistike RK 2013. Ohrana okruzhayushchej sredy i ustojchivoe razvitie Kazahstana 2008-2012. Statisticheskij sbornik [Environmental protection and sustainable development of Kazakhstan. Statistical Bulletin]. Astana pp. 42.

Akimat Kostanajskoj oblasti 2015. Vodnye resursy [Water resources] [online]. [Access 14.10.2015]. Available at: http://kostanay.gov.kz/akim-oblasti/analitika/prirodnyeresursy-i-prirodopolzovanie/vodnye-resursy/index.php

Burlibaev M.J., Amirgaliev N.A., Murtazin E.Zh., Shenberger I.V., Perevalov A.S., Burlibaeva D.M. 2012. Sovremennoe sostoyanie gidrohimicheskogo rezhima i toksikologicheskih parametrov $\mathrm{v}$ transgranichnoj reke Ertis i harakter ih transformacii [The current state of the hydrochemical regime and toxicological parameters in transboundary river Irtysh and the nature of their transformation]. Gidrometeorologiya i ekologiya. No. 4 p. 118-135.

Burlibaev M.J., Murtazin E.ZH., Shenberger I.V., BurLIBAEVA D.M. 2012. Sovremennoe sostoyanie zagryaznenie rek Central'noj Azii po transgranichnym stvoram v predelah territorii Kazahstana. V: Vodnomu sotrudnichestvu stran Central'noj Azii - 20 let: opyt proshlogo i zadachi budushchego [The current state of pollution of the rivers of Central Asia on the transboundary river stations within the territory of Kazakhstan. In: Water cooperation in Central Asia - 20 years: past experience and future challenges]. Central'no-aziatskaya mezhdunarodnaya nauchno-prakticheskaya konferenciya. Almaty, 20-21 sentyabrya 2012 g. [Access 10.11.2014]. Available at: www.libed.ru/ konferencii-mehanika/464063-1-centralno-aziatskayamezhdunarodnaya-nauchno-prakticheskayakonferenciya-vodnomu-sotrudnichestvu-strancentralnoy-azii.php

Burlibaev M.J., Amirgaliev N.A., MurtaZin E.ZH., Shenberger I.V., Perevalov A.S., Burlibaeva D.M. 2013. Sovremennye sostoyaniya gidrohimicheskogo rezhima $\mathrm{i}$ toksikologicheskih parametrov $\mathrm{v}$ transgranichnyh rekah Balkash-Alakol'skogo bassejna [The 
current hydrochemical regime and toxicological parameters in transboundary rivers Balkhash-Alakol basin]. Gidrometeorologiya i ekologiya. No. 1 p. 117-128.

Burlibaev M.J., Amirgaliev N.A., Shenberger I.V., PerEVAlov A.S., Burlibaeva D.M. 2013. Sovremennye gidroekologicheskie i toksikologicheskie problemy transgranichnogo stoka rek bassejna Zhaika (Urala) i harakter transformacii ih parametrov [Current hydroecological and toxicological issues of transboundary flow of Zhaik (Urals) basin rivers and the nature of the transformation parameters]. Gidrometeorologiya i ekologiya. No. 2 p. 76-107.

Burlibaev M.J., Amirgaliev N.A., Shenberger I.V., PerEVAlOV A.S., BuRlibaeva D.M. 2013. Sovremennyj rezhim gidrohimicheskih i toksikologicheskih parametrov transgranichnogo stoka reki Syrdar'i i harakter ih transformacii v predelah territorii Kazahstana [The current regime of hydrochemical and toxicological parameters of cross-border flow of the Syrdarya river and the nature of their transformation within the territory of Kazakhstan]. Gidrometeorologiya i ekologiya. No. 3. p. 141-160.

DEJNEKA V.K. 1996. Tehnicheskij otchet o rezul'tatah issledovanij himicheskogo i mikrokomponentnogo sostava poverhnostnyh rechnyh vod i donnyh osadkov vodotokov i vodohranilishch Kustanajskoj oblasti za $1995 \mathrm{~g}$. [Technical report on the results of studies of the chemical and microcomponent composition of surface river waters and the sediments of watercourses and reservoirs of Kostanay region in 1995]. Kustanaj. Ministerstvo geologii i ohrany nedr Respubliki Kazahstana pp. 77.

DEJNEKA V.K. 2010. Reka Tobol v Kazahstane (monografiya) [The Tobol River in Kazakhstan (monograph)]. Kostanay. Izd. Kostanay pp. 336.

Dzhuatova S.A., SEYdullaeva B.A. 2014. Analiz vodnyh resursov Kazahstana [Analysis of water resources of Kazakhstan] [online]. Almaty. Institut ekonomicheskih issledovanij ERI [Access 31.10.2014]. Available at: www.economy.kz/analitics/971/10799

GAZALIYEV A.M. (ed.) 2014. Ekologiya i zdorov'e nacii. [Ecology and health of the nation]. Sbornik 7. Karaganda. Izd. Karagandinskogo gosudarstvennogo tehnicheskogo universiteta pp. 100.

Goskomgidromet SSSR 1986. Vremennye metodicheskie ukazaniya po kompleksnoj ocenke kachestva poverhnostnyh i morskih vod po gidrohimicheskim pokazatelyam [Interim guidelines for a complex assessment of the quality of surface and marine waters acc. to hydrochemical indices]. Utv. Goskomgidromet SSSR $22.09 .1986 \mathrm{~g}$.

GRID-Arendal 1998. Faktory vozdejstviya na vodnye resursy. V: Otchet o sostoyanii okruzhayushchej sredy $v$ Kazahstane [Report on the state of the environment in Kazakhstan] [online]. [Access 31.11.2015]. Available at: http://enrin.grida.no/htmls/kazahst/soe2/soe/nav/ water/wateruse.htm

GrinYAEV S.N., Fomin A.N. 2009. Aktual'nye voprosy primeneniya mehanizma birzhevoj torgovli dlya resheniya vodno-energeticheskih problem Central'noj Azii. Analiticheskij doklad [Pressing questions of application of the mechanism of exchange trade to address waterenergy problems in Central Asia. Analytical report]. Moskva. Centr strategicheskih ocenok $\mathrm{i}$ prognozov pp. 52.

Institut geografii Respubliki Kazahstan 2010. Nacional'nyj atlas Respubliki Kazahstan. T. 1. Prirodnye usloviya i resursy [The national atlas of the Republic of Kazakh- stan. Vol. 1. Natural conditions and resources]. Almaty. VIT BRAND pp. 150.

Kalinnikov V.T., MaKarov V.N., Makarov D.V. 2002. Puti snizheniya otricatel'nogo vliyaniya na okruzhayushchuyu sredu sul'fidsoderzhashchih othodov [Ways to reduce the negative environmental impact of waste sulfide]. Geoekologiya, Inzhenernaya geologiya, Gidrogeologiya, Geokriologiya. No. 5 p. 425-435.

Kazgidromet 2011. Harakteristika urovnya zagryaznennosti vod i himicheskij sostav vody. Bassejn reki Tobol [The characteristics of the level of water pollution and the chemical composition of water. The basin of the Tobol River]. Astana p. 4-7.

Kazgidromet 2012. Informacionnyj byulleten' o sostoyanii okruzhayushchej sredy Respubliki Kazahstan za 2011 god [Newsletter on the state of the environment of the Republic of Kazakhstan in 2011]. Almaty pp. 29.

KRISTENSEN P. 2004. The DPSIR Framework. In: Detailed assessment of the vulnerability of water resources to environmental change in Africa using river basin approach [online]. Nairobi, Kenya. UNEP Headquarters. [Access 31.10.2014]. Available at: wwz.ifremer.fr/dce/content/ download/69291/913220/file/DPSIR.pdf

KURTOV A. 2014. Vodnye resursy kak prichina konfliktov v Central'noj Azii [Water resources as a cause of conflict in Central Asia] [online]. Svobodnaya mysl'. No. 4 [Access 29.05.2015]. Available at: swom.info/entry/ 350-vodnye-resursy-kak-prichina-konfliktov-vcentralnj/

Medeu A.R., Malkovsky I.M., ISKakov N., Toleubayeva L.S. 2012. Vodnaya bezopasnost' Respubliki Kazahstan: problemy i resheniya [Water security of the Republic of Kazakhstan - problems and solutions]. Almaty. InVodGeo pp. 200.

Mironenko V.A., Molskiy E.V., Rumynin V.G. 1988. Izuchenie zagryazneniya podzemnyh vod $\mathrm{v}$ gornodobyvayushchih rajonah [The study of groundwater pollution in mining areas]. Leningrad. Nedra pp. 279.

MOOS 2012. Metodicheskie rekomendacii po kompleksnoj ocenke kachestva poverhnostnyh vod po gidrohimicheskim pokazatelyam [Guidelines for a complex assessment of the quality of surface waters by hydrochemical indicators]. Astana pp. 67.

PaVlichenKo L.M., Bimagambetova L.N., AKTYMBaEVA A.S. 2009. Ocenka vklada g. Kostanaj v transgranichnyj perenos medi na osnove chislennogo eksperimenta po ploskoj modeli turbulentnoj diffuzii zagryaznyayushchih veshchestv $\mathrm{v}$ reke Tobol [Assessing the contribution of Kostanay city in transboundary transport of copper based on a numerical experiment on a flat model of turbulent diffusion of pollutants in the Tobol River]. Westnik Kaz-NU. Seriya geograficheskaya. No. 2 p. 51-57.

PDK, OBUV 1990. Obobshchennyj perechen' PDK i OBUV vrednyh veshchestv dlya rybohozyajstvennyh vodoemov [A generalized list of MAC and OSLI of harmful substances for fishery water bodies]. Moskva pp. 42.

PK Institut Kazgiprovodhoz 2006. Shema kompleksnogo ispol'zovaniya i ohrany vodnyh resursov bassejna $r$. Tobol na territorii Respubliki Kazahstan. T. II. Vodnye ob"ekty, resursy i prirodoohrannye meropriyatiya. Kn. 2. Kachestvo vod i ekologicheskoe sostoyanie vodnyh ob"ektov [Scheme of complex use and protection of water resources of the Tobol River basin in area of the Republic of Kazakhstan. Vol. 2. Water bodies, resources and environmental protection measures. Book 2. Water 
quality and ecological state of water bodies]. Almaty pp. 80.

PORYADIN V.I. 2014. Ekosistemnye resursy podzemnyh vod Kazahstana: metodologiya ocenki [Ecosystem groundwater resources of Kazakhstan: assessment methodology]. Izvestiya NAN RK. Seriya geologii i tehnicheskih nauk. No. 5 p. $47-57$.

Pravitel'stvo RK 2010. Programma integrirovannogo upravleniya vodnymi resursami i povysheniya effektivnosti vodopol'zovaniya Respubliki Kazahstan do 2025 goda [Integrated water resources management and improvement of water use efficiency in Kazakhstan till 2025]. Postanovlenie Pravitel'stva RK ot 11 oktyabrya 2010 g.

PROON 2004. Obzor «Vodnye resursy Kazahstana v novom tysyacheletii» [Review of "Water Resources of Kazakhstan in the new millennium"]. Almaty pp. 132.

PROON 2005. Doklad PROON o chelovecheskom razvitii v Central'noj Azii [UNDP report on human development in Central Asia] [online]. Regional'noe byuro PROON po stranam Evropy i Sodruzhestva Nezavisimyh Gosudarstv. ISBN 92-95042-65-2. [Access 11.11.2015]. Available at: http://www.un.org/ru/ development/hdr/central_asia_2005.pdf

RGP KazNIIJEK. AO NPO Evrazijskij centr vody 2011. Otchet o nauchno-issledovatel'skoj rabote «Kompleksnaya ocenka gidroekologicheskih problem TobolTorgajskogo vodnogo bassejna» (promezhutochnyj) [Report on the research work "Complex assessment of hydro-ecological problems of the Tobol Torgai water basin (interim)"]. Astana pp. 230.

Sanitarno-epidemiologicheskie pravila i normy. No. 3.02.00304 . Sanitarno-epidemiologicheskie trebovaniya po ohrane poverhnostnyh vod ot zagryazneniya [Sanitary-epidemiological rules and norms. No. 3.02.003-04. Sanitary requirements for the protection of surface waters from pollution]. Almaty. Minzdrav pp. 93.
SEVERSKIY I. 2004. Water-related problems of Central Asia: Some results of the (GIWA) International Water Assessment Program. AMBIO. Vol. 33. Iss. 1-2 p. 52-62.

Sidorova L. 2008. Gosudarstva Central'noj Azii: Problemy sovmestnogo ispol'zovaniya transgranichnyh vodnyh resursov [The states of Central Asia: The problems of sharing of transboundary water resources]. Central'naya Aziya i Kavkaz. No. 1 (55) p. 92-105.

Upravlenie po ekonomike i planirovaniyu 2011. Social'no-ekonomicheskij pasport Kostanajskoj oblasti [Socio-economic passport of the Kostanay region]. Kostanaj pp. 83.

URYVAEV V.A. (ed.) 1959. Resursy poverhnostnyh vod rajonov osvoeniya celinnyh i zalezhnyh zemel'. T. 11. Kustanajskaya oblast' [Surface water resources in areas of virgin and fallow lands. Vol. 11. Kostanay region]. Leningrad. Gidrometeoizdat pp. 299.

Veselov V.V., Mahmutov T.T., Skidanov A.T. 1993. Tehnogennye gidrogeologicheskie processy na zhelezorudnyh mestorozhdeniyah Severnogo Kazahstana [Man-made hydrogeological processes on the iron-ore deposits in Northern Kazakhstan]. Almaty. Gylym. ISBN 5-628-01116-9 pp. 320.

Wikipedia undated. Tobol River [online] [Access 11.11.2015] Available at: https://en.wikipedia.org/wiki/ Tobol_River

ZHAKAEV M.A. 2007. Sanitarno-gigienicheskaya harakteristika reki Tobol $\mathrm{v}$ usloviyah ekspluatacii kaskada vodohranilishch $\mathrm{v}$ predelah Kostanajskoj oblasti. V: Sovremennye problemy Tobol-Torgajskogo bassejna [Sanitary-hygienic characteristics of the Tobol River in using of the reservoirs cascade within the Kostanay region. In: Recent problems in Tobol-Torgay basin]. Informacionnyj byulleten'. Almaty. PROON Kazakhstan p. $22-25$.

\section{Gulnara YUNUSSOVA, Józef MOSIEJ}

\section{Transgraniczne priorytety gospodarki wodnej w państwach Azji Środkowej na przykładzie zlewni rzeki Tobol na terytorium Kazachstanu}

\section{STRESZCZENIE}

Główną przesłanką opracowania artykułu było przedstawienie problemów transgranicznego gospodarowania wodą w jednym z największych pod względem obszaru krajów świata (9. miejsce na świecie pod względem powierzchni) i największego w Azji Środkowej - Kazachstanu. W społeczności naukowej zajmującej się zarządzaniem zasobami wodnymi Kazachstan postrzegany jest zwykle jako kraj związany z dorzeczami dwóch dużych unikatowych bezodpływowych akwenów - Morzami Aralskim i Kaspijskim. Praca dotyczy tej części Kazachstanu, która położona jest w zlewisku Oceanu Arktycznego.

Zmiany w transgranicznym zarządzaniu zasobami wodnymi w państwach Azji Środkowej spowodowały konieczność aktualizacji priorytetów, a przede wszystkim konieczność wprowadzenia kryteriów jakościowych w miejsce dotychczas stosowanych - wartości odpływu - i zaspokojenia potrzeb wszystkich użytkowników. W artykule przedstawiono na przykładzie rzeki Toboł, że nawet w przypadku deficytu wody możliwe jest uwzględnienie priorytetów jakościowych $\mathrm{w}$ transgranicznym zarządzaniu zasobami wodnymi.

Zanieczyszczenia antropogeniczne pozostają priorytetem $\mathrm{w}$ transgranicznym gospodarowaniu zasobami wodnymi rzeki Toboł, będącej dopływem rzek Ob i Irtysz, należącej do zlewiska Morza Karskiego i znajdującej się na terytorium Kazachstanu oraz Rosji. Stwierdzono, że jakość wody w rzekach w regionie była stabilna w okresie 2000-2010, a jej jakość była kształtowana czynnikami naturalnymi. Główne zanieczyszczenia w zlewni to metale ciężkie i substancje organiczne wprowadzone ze źródeł antropogenicznych.

Słowa kluczowe: Irtysz, Ob, system wodnogospodarczy Tobot-Torgaj, zanieczyszczenia antropogeniczne 


\section{Gulnara YUNUSSOVA, Józef MOSIEJ}

Трансграничные приоритеты управления водными ресурсами в странах Центральной Азии на примере реки Тобол в Казахстане

\section{PЕЗЮME}

Идея статьи заключается в том, чтобы представить вопросы управления трансграничной водой, в одной из крупнейших стран мира (занимает 9 место в мире по площади) - Казахстане. В научном сообществе, занимающим управлением водными ресурсами, Казахстан, как правило, ассоциируется с площадью водосбора двух крупных закрытых водоёмов (без возможности оттока) - Аральского моря и Каспийского моря. Статья относится к той части Казахстана, которая расположена в водосборе Северного Ледовитого Океана.

Изменения в трансграничном управлении водными ресурсами стран Центральной Азии актуализировали вопрос о приоритетности проблемы загрязнения речных вод в сравнении с проблемами стока и водораспределения. В данной работе продемонстрировано, что анализируя динамики стока рек, их водопотребления и загрязнения, можно установить приоритетность этих аспектов для водного менеджмента.

На примере Тобол-Торгайского бассейна Казахстана показано, что для бассейнов такого типа антропогенное загрязнение остается приоритетным фактором трансграничного водного менеджмента. Бассейн реки Тобол, впадающей в реки Иртыш и Обь, относится к бассейну Карского моря и расположен на территории Казахстана и России. Тобол-Торгайский водохозяйственный бассейн, расположенный в Костанайской области Казахстана, охватывает верховья реки Тобол и ее притоки. Установлено, что качество воды рек области стабильно в течение изучаемого десятилетия и по-прежнему формируется в основном природными факторами. Приоритетными загрязнениями в изучаемом бассейне являются тяжелые металлы и органические вещества, вносимые антропогенными источниками.

Ключевые слова: антропогенный привнос, загрязнение, реки Иртыши и Обь, Тобол-Торгайский водный бассейн 